\title{
Groundwater Radon-222 Concentrations in Antelope Creek, Idaho: Measurement and Interpolation
}

\author{
Bhushan Gokhale* and Solomon Leung
}

Stop 8060 The Civil and Environmental Engineering Department, College of Engineering, Idaho State University, Pocatello, Idaho 83209, USA

\begin{abstract}
Groundwater samples were collected from eight wells in remote Antelope Creek valley, Idaho. Seven out of eight locations showed that groundwater ${ }^{222} \mathrm{Rn}$ concentrations were much greater than $11 \mathrm{~Bq} / \mathrm{L}(300 \mathrm{pCi} / \mathrm{L})$, a maximum contaminant level (MCL) proposed by United States Environmental Protection Agency (USEPA).

Rock and soil samples collected near the sampling wells revealed that ${ }^{238} \mathrm{U}$ contents were between 0.55 to $6.41 \mathrm{ppm}$. Minerals collected from different regions of the country with similar ${ }^{238} \mathrm{U}$ contents also showed high concentrations of ${ }^{222} \mathrm{Rn}$ in the groundwater. An interpretation technique using a Geographic Information System (GIS) software with available information also indicated a clear correlation between the rock types and ${ }^{222} \mathrm{Rn}$ concentrations in the groundwater.

Several cancer rates near the study area reported to be higher than national average. Many factors can be affecting ${ }^{222} \mathrm{Rn}$ in the groundwater, what may these factors be in the study area and if the ${ }^{222} \mathrm{Rn}$ concentration is a contributing factor to certain high cancer rates in the area remain to be subjects of interest.
\end{abstract}

Keywords: Groundwater quality, Geographic information systems, Radon, Health assessment, Radioactive decay, Liquid scintillation counter, Maximum contaminant Level (MCL).

\section{INTRODUCTION}

Radon-222 $\left({ }^{222} \mathrm{Rn}\right)$ is a naturally occurring radionuclide; it is a gas which is formed by a series radioactive decay of uranium-238 $\left({ }^{238} \mathrm{U}\right)$. Radium $-226\left({ }^{226} \mathrm{Ra}\right)$ is the parent radionuclide of ${ }^{222} \mathrm{Rn}$ in the decay series and ${ }^{226} \mathrm{Ra}$ is found in a wide variety of rocks and soils. Volcanic rocks in the Rocky Mountain region possess a high ${ }^{222} \mathrm{Rn}$ generating potential. Therefore colluvium and alluvium originated from uranium bearing rocks present moderate to high ${ }^{222} \mathrm{Rn}$ generating potential and they are abundant in Idaho [1]. Radon is the number one cause of lung cancer among non-smokers; overall, radon is the second leading cause of lung cancer and is responsible for about 21,000 lung cancer deaths every year [2].

${ }^{222} \mathrm{Rn}$ gas generated from the colluvium and alluvium can enter groundwater by dissolution. Numerous factors such as geology, geochemical properties of parent radionuclides, hydrological conditions, abundance of parent radionuclides, and radionuclides sorbed by the rocks or soils are potential parameters that can affect the concentration of ${ }^{222} \mathrm{Rn}$ in groundwater [3].

As an effort to increase general awareness of radon, United States Environmental Protection Agency (USEPA) is

*Address correspondence to this author at the Stop 8060 The Civil and Environmental Engineering Department, College of Engineering, Idaho State University, Pocatello, Idaho 83209, USA; Tel: (208) 313-1480; E-mail: gokhales@gmail.com in a campaign to promote radon testing and mitigation, and radon resistant construction practices. The month of January is recognized as National Radon Action Month by the USEPA [4]. The USEPA recommended zero concentration of ${ }^{222} \mathrm{Rn}$ in drinking water and this has been proposed as maximum contaminant level goal (MCLG) since 1999; however, this limit is a non-enforceable limit [5].

In the Safe Drinking Water Act Amendments of 1996 the USEPA has recommended the maximum contaminant level (MCL) for ${ }^{222} \mathrm{Rn}$ in drinking water as $11 \mathrm{~Bq} / \mathrm{L}(300 \mathrm{pCi} / \mathrm{L})$. This limit should be followed if there is no indoor air multimedia mitigation (MMM) program implemented for the public water treatment and supply system. If a MMM program is implemented, then the limit for ${ }^{222} \mathrm{Rn}$ becomes $148 \mathrm{~Bq} / \mathrm{L}$ (4000 pCi/L) [5]. Presumably, the MMM program would reduce the fugitive ${ }^{222} \mathrm{Rn}$ gas escaped from the drinking water to an acceptable risk level. Although this rule should only be followed by public water suppliers, private wells and water providers should also follow the recommended MCL due to health concerns. Idaho Department of Environmental Quality (IDEQ) neither regulates ${ }^{222} \mathrm{Rn}$ in drinking water, nor does it have any MMM programs for the state [6]. Nevertheless, if human health is a priority, ${ }^{222} \mathrm{Rn}$ concentration in the drinking water should be below $11 \mathrm{~Bq} / \mathrm{L}$ when it is consumed domestically without a MMM program.

Radon from the groundwater can enter our living environment by various routes: such as $\mathrm{Rn}$ gas released from water in showering, dishwashing, and laundrying [7]. Direct inhalation is probably the most likely mechanism that radon 
enters into our body, although other route such as dermal sorption is possible. High concentrations of ${ }^{222} \mathrm{Rn}$ in water may pose a serious health threat to human as ${ }^{222} \mathrm{Rn}$ is a known carcinogen [5]. Hopke et al. [8] have listed inhalation and ingestion risk for ${ }^{222} \mathrm{Rn}$ in water: the authors estimated a lifetime risk of lung cancer for a mixed population that included smokers and nonsmokers in men and women as a result of air exposure to ${ }^{222} \mathrm{Rn}$ generating from ${ }^{222} \mathrm{Rn}$ water with concentration of $0.0009 \mathrm{~Bq} / \mathrm{L}$ as $1.3 \times 10^{-8}$. For the same ${ }^{222} \mathrm{Rn}$ water concentration the lifetime risk of stomach cancer was reported as $0.2 \times 10^{-8}$, the lung cancer risk was more than six times of the stomach cancer risk. Although these risk factors are relatively low, the aforementioned concentration in water from the report was also orders of magnitude $(10,000$ times) lower than the $11 \mathrm{~Bq} / \mathrm{L}$ limit. The risk factors would be drastically higher if the proposed radon MCL were used in the work of Hopke et al.

In this study, we have selected this Antelope Creek area in southeastern Idaho that is located near many abundant $\mathrm{U}$ mines; although the geological information in this area is mostly unknown in literature and to the public, we hypothesized that the ground water in the area would be subjected to high radon concentration because of its locality. The recent energy crisis has forced government and industry to reevaluate the potential of nuclear energy, thus, increasing mining activities are expected in the area in near future. If elevated radon concentration is found in the groundwater, then further study to research if $U$ mining activities would increase radon concentration in groundwater may be necessary. Although the area is sparsely populated, elevated radon concentration in the drinking water is still a potential health concern and should not be overlooked. Furthermore, the Antelope Creek valley can serve as a case study that can be used as a guiding example for comparisons with other regions in the world that have similar geological setting but are more populated.

We have collected groundwater samples from eight different wells spread out along the Big Lost River in the study area, samples were then analyzed for the ${ }^{222} \mathrm{Rn}$ concentrations. Also, grid samples of rocks and soils from colluvium and alluvium were collected from the area along the sample wells to gain better understanding of the rock formations in the area. Assuming these samples are representations of the rock formations of the study area, information from the compositions of the grid samples was used to compare with literature to evaluate how the rock formations may affect groundwater radon contents. Finally, a Geographic Information System (GIS) technique was used with the available information to help visualize the Rn distribution in groundwater for the area.

In this study, we assume all the radon species in the groundwater were ${ }^{222} \mathrm{Rn}$ because ${ }^{222} \mathrm{Rn}$ is the predominant species in groundwater and the proposed MCL of $11 \mathrm{~Bq} / \mathrm{L}$ $(300 \mathrm{pCi} / \mathrm{L})$ as the reference concentration for our discussions.

\section{THE STUDY AREA}

The study area is roughly rectangular in shape and is located on the border between Custer County and Butte County, Idaho. The area is located near the northwestern corner of the Idaho National laboratory (INL) site. The coordinates at the southwest and northeast ends of the area are approximately $43^{\circ} 40^{\prime} \mathrm{N} 113^{\circ} 38^{\prime} \mathrm{W}$ and $43^{\circ} 46^{\prime} \mathrm{N} 113^{\circ} 23^{\prime} \mathrm{W}$, respectively.

The Antelope Creek valley stretches from southwest to northeast. The valley contains alluvium (river deposits) and colluvium (hillslope deposits) and has bedrock outcrops above the valley floor. Fig. (1) shows the locations where groundwater samples were collected from private wells in the Antelope Creek drainage basin. Antelope Creek is a youthful, intermittent stream which flows into the Big Lost River near Darlington, Idaho. A fault zone borders the south side of the valley.

The Antelope Creek area of Idaho is an isolated valley, many abandoned uranium mines are also scattered in the region. The area has shown groundwater ${ }^{222} \mathrm{Rn}$ concentrations up to $74 \mathrm{~Bq} / \mathrm{L}$ at the only monitoring well in Lost River by Idaho Department of Water Resources (IDWR) [9] as it is indicated in Fig. (1).

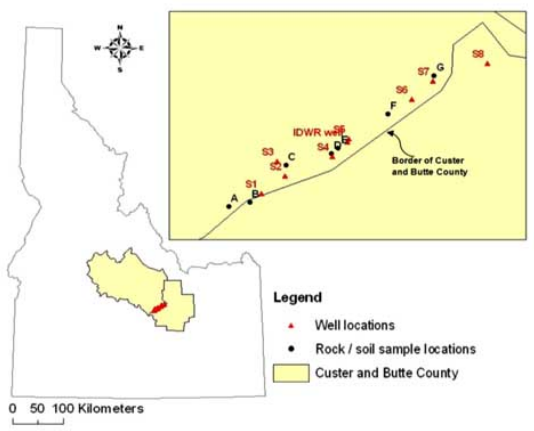

Fig. (1). Location of Antelope Creek in Idaho and the sampling locations of wells, rocks/soils, and IDWR monitoring well.

\section{METHOD AND MATERIALS}

\subsection{Sample Collections}

\subsubsection{Water Samples}

The selected sampling locations in the Antelope Creek area were in private lands. Groundwater pumps were used on these locations. With the owners' permission groundwater samples were collected. A protocol developed by the USEPA was used for the water sampling [10].

Water samples were collected as follows: Before opening the tap it was made sure that there was no aerator present on the faucet. After opening the tap, water was allowed to flow for approximately 15 minutes to ensure a representative sample. The flow was regulated to avoid turbulence which might allow ${ }^{222} \mathrm{Rn}$ gas to escape from the groundwater. A small diameter Tygon tube and a bucket were used to collect the water. One end of the tubing was connected to the tap and the other end was placed at the bottom of the bucket. The bucket was filled slowly in order to avoid aeration and water was allowed to spill over the rim of the bucket. The bucket was then emptied once and refilled with the water. The water was again allowed to spill over the rim of the bucket. A $250 \mathrm{~mL}$ glass sample bottle specially designed for ${ }^{222} \mathrm{Rn}$ measurement was then slowly immersed into the bucket. Once the bottle was completely submerged, the tubing was placed inside the bottle while the bottle was still in 

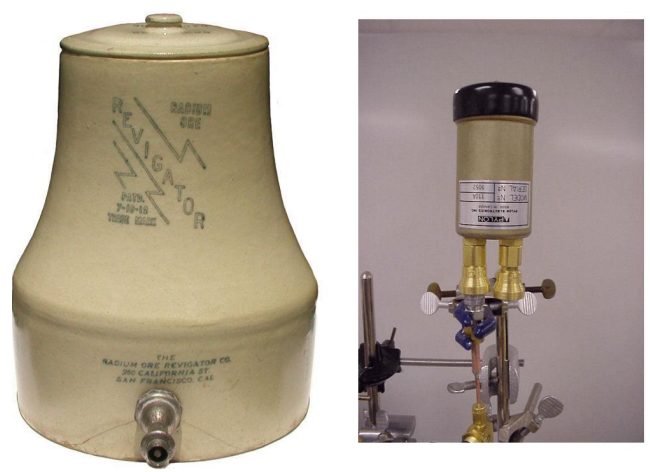

a.

b.

Fig. (2). a. A Revigator jar . b. A Lucas cell.

the bucket. After filling the bottle, the tubing was removed and a Teflon lined cap was placed to seal the bottle tightly while the bottle was still in the bucket. The bottle was then removed from the bucket and inverted to check for air bubbles. Once it was ensured that there was no headspace, the cap of the bottle was wrapped with electrical tape.

At every location three water samples were collected. Each sample's identification and time of collection were recorded and GPS locations of all the wells were also recorded. After collection, the bottles were immediately transferred to a container with ice. The samples were brought to the laboratory on the same day for analysis. The collected water samples showed no visible turbidity and were not filtered. It was assumed that the ${ }^{222} \mathrm{Rn}$ in water was mostly dissolved and the concentration was governed by ${ }^{222} \mathrm{Rn}$ solubility in water. The ${ }^{222} \mathrm{Rn}$ solubility in water was reported to be $510 \mathrm{~cm}^{3} / \mathrm{L}$ at $0^{\circ} \mathrm{C}$ and inversely proportional to temperature [11].

\subsubsection{Rock and Soil Collections}

Rock and soil samples were collected from 7 locations along the boundary of Custer County and Butte County and in the neighborhood of the 8 sampling wells. These 7 locations were selected to be as closed to the sample wells as possible where sample collections were permitted (Fig. 1). From each sampling site, in a $0.6 \times 0.6 \mathrm{~m}^{2}$ grid, the top $5 \mathrm{~cm}$ of soil was removed and rock/soil samples were collected accordingly. After samples were collected and brought back to the laboratory, these samples were examined and classified. Classified rock samples were then sent to a commercial laboratory for compositional analysis.

\subsection{Sample Analyses}

\subsubsection{Water Samples}

Three water samples (A, B, and C) were collected from each well (S1-S8) for the ${ }^{222} \mathrm{Rn}$ analysis. The analytical procedures were divided into 4 steps as described in the following:

(1) Measurement of ${ }^{222} \mathrm{Rn}$ concentration of water sample from a Revigator jar (radium ore) as a comparison standard by a Lucas cell.

A $20 \mathrm{ml}$ of water sample was obtained from a Revigator jar with an impinger. The Revigator jar (Fig. 2a) is lined with radium ore and filled with deion- ized water for some time that serves as a source of water standard with ${ }^{222} \mathrm{Rn}$ at relative high concentration $(>50 \mathrm{~Bq} / \mathrm{L})$. The Revigator water is used as a comparison standard in water sample measurements. The Revigator sample was then aerated to strip out the ${ }^{222} \mathrm{Rn}$ into the air, the air was vacuumed into a Lucas cell for the measurement of ${ }^{222} \mathrm{Rn}$. A Lucas cell (Model number 110A) (Pylon Electronics Inc., model number 110A, Ottawa, Canada) consists of a cylindrical metal container with inside walls coated with zinc sulfide $(\mathrm{ZnS})$. A clear window is provided on the cell so that scintillations can be counted. Phosphorescence is observed when an alpha particle strikes the $\mathrm{ZnS}$ coated inside surface of the cell. The emitted light is detected by a photomultiplier (PM) tube (Lundlum Measurements, model number 182, Sweetwater, TX, USA) and translated into an electrical signal which is the measurement of the ${ }^{222} \mathrm{Rn}$ activity [12]. A Lucas cell is shown in Fig. (2b).

(2) PM tube calibration

The PM tube was calibrated with a Co-60 standard (North American Scientific, Model CAL 2601, Chatsworth, CA, USA) according to manufacturer's recommendations before it was used to measure the concentration of ${ }^{222} \mathrm{Rn}$ stripped from the water sample into the Lucas cell.

(3) Water sample and standard Revigator water measurements from Liquid Scintillation Counter (LSC)

The water samples and a Revigator water sample were analyzed using a liquid scintillation counter (LSC) (Packard Tri-Carb 2750TR, Ramsey, Mn, USA) for ${ }^{222} \mathrm{Rn}$ measurements [13]. The LSC also measured ${ }^{222} \mathrm{Rn}$ concentrations with a PM tube. Ten $\mathrm{mL}$ of the water sample was taken out of the sample bottle using a $20 \mathrm{~mL}$ syringe and transferred to a 20 $\mathrm{mL}$ borosilicate glass scintillation vial. Ten $\mathrm{mL}$ of scintillation cocktail (Perkin Elmer high efficiency mineral oil scintillator) was added to the vial and the vial was vigorously shaken to mix the two liquids. ${ }^{222} \mathrm{Rn}$ is highly soluble in organic solvents such as the scintillation cocktail and thus most of the ${ }^{222} \mathrm{Rn}$ in the water sample was extracted into the cocktail. The vial was then put onto an autosampler of the LSC for the ${ }^{222} \mathrm{Rn}$ measurement.

${ }^{222} \mathrm{Rn}$ concentration is measured by means of $\alpha$ particles emitted from the disintegration of ${ }^{222} \mathrm{Rn}$. However, the vial containing the extracted ${ }^{222} \mathrm{Rn}$ in the cocktail takes about 3 hours before an equilibrium is reached with the $\alpha$-particles, proper measurement of ${ }^{222} \mathrm{Rn}$ can only be taken by the scintillation counter after the 3-hour equilibrium time. A typical continuous $\alpha$-particle counts with time from a Revigator water sample is given in Fig. (3), as shown, the $\alpha$-particle counts would reach an equilibrium (the peak) at about 3 hours and then exhibit a first-order decay kinetics thereafter. Thus, all our ${ }^{222} \mathrm{Rn}$ concentration measurements followed this scheme. Due to the fact that the ${ }^{222} \mathrm{Rn}$ in the water 


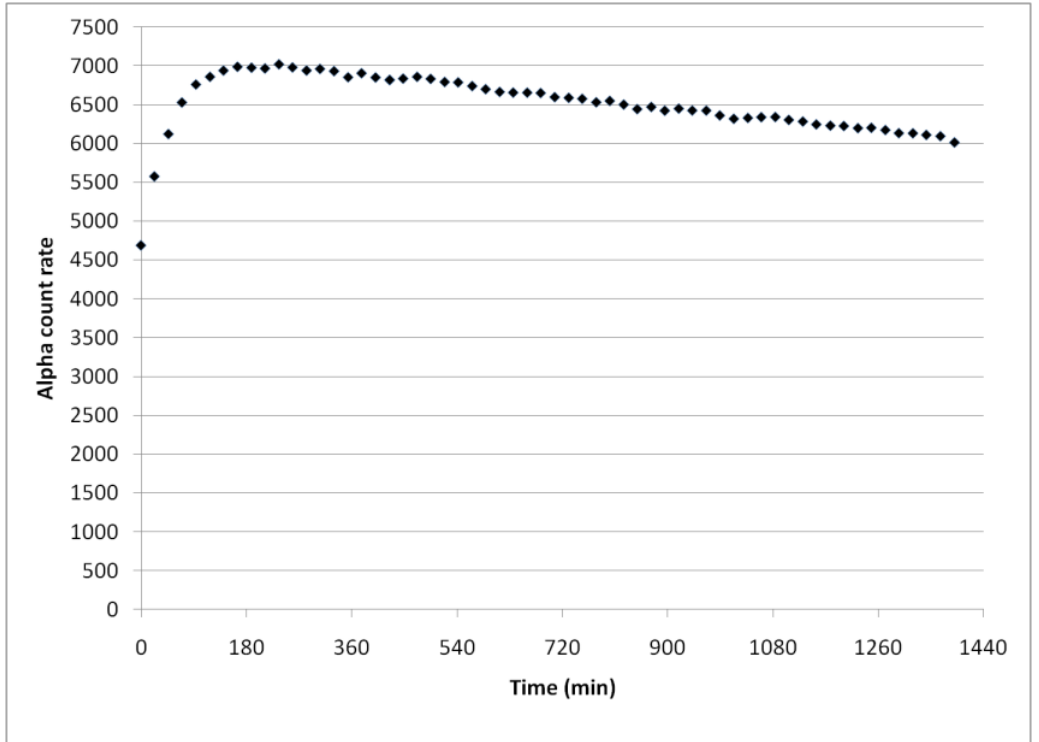

Fig. (3). A typical ${ }^{222} \mathrm{Rn}$ decay curve measured from a Revigator water sample.

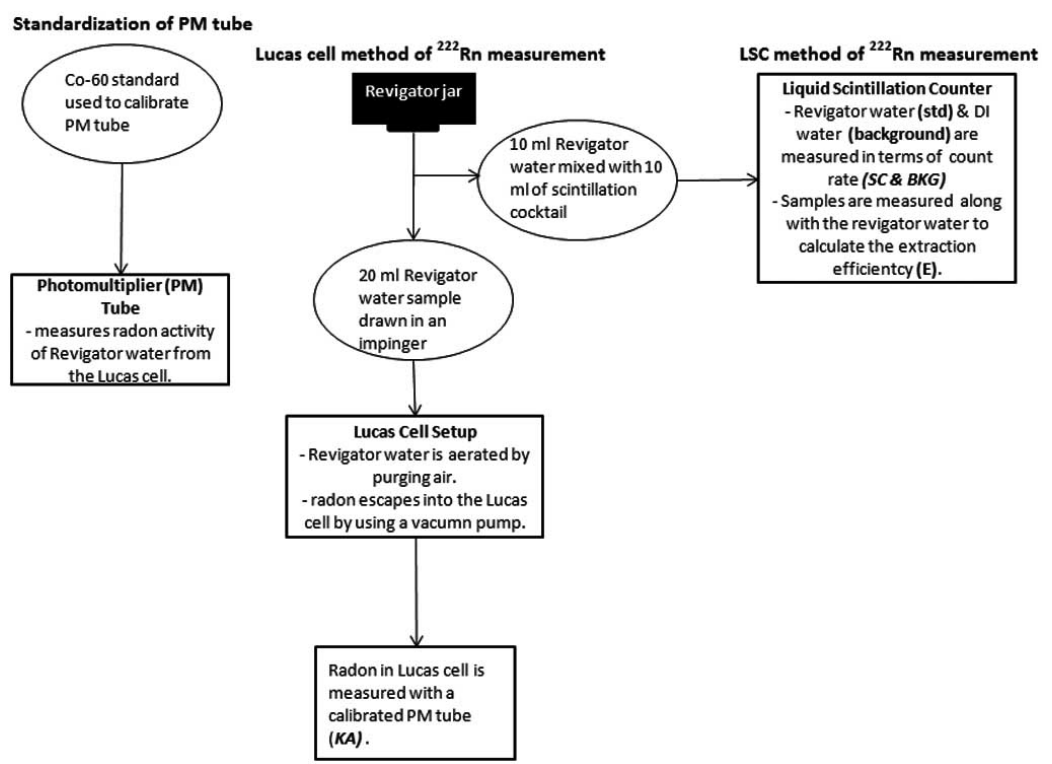

Fig. (4). Schematic diagram of water sample and Revigator water standard measurements.

samples would continuously decay with time, therefore all the water sample concentrations were backcalculated to a reference time when samples were collected for proper comparisons.

(4) Extraction efficiency calculated from Revigator water standard with measurements from LSC and Lucas cell

The measurement of ${ }^{222} \mathrm{Rn}$ of the Revigator water from the LSC was compared with the measurement of the same Revigator water from the PM tube as described above in Part (1). This comparison of measurements of the same Revigator water with two different methods provided an extraction efficiency factor (E) that was used to calculate the actual ${ }^{222} \mathrm{Rn}$ concentration of water samples.

A schematic diagram of the how the water samples and Revigator water (standard) were analyzed is shown in
Fig. (4). Concentration of water samples measured by LSC was calculated using the following formulas.

Concentration $=(\mathrm{SC}-\mathrm{BKG}) /(0.010 \times 2.22 \times \mathrm{E})$

where:

Concentration is expressed in $\mathrm{pCi} / \mathrm{l}$,

$\mathrm{SC}=$ the sample count rate (counts $/ \mathrm{min})$,

$\mathrm{BKG}=$ the background count rate,

$0.010=$ the volume sample used in liters,

2.22 = the conversion factor from disintegrations per minute (dpm) to $\mathrm{pCi}$,

$\mathrm{E}=$ the extraction efficiency expressed as decimal fraction.

Extraction efficiency is expressed as:

$\mathrm{E}=\left(\mathrm{SC}_{\mathrm{v}}-\mathrm{BKG}\right) / \mathrm{KA}$

where: 
$\mathrm{SC}_{\mathrm{v}}=$ The sample count rate from Revigator water measured with LSC,

$\mathrm{BKG}=$ The background count rate,

$\mathrm{KA}=$ Count rate of the standard with Revigator water measured by the Lucas cell (dpm).

After obtaining the measured ${ }^{222} \mathrm{Rn}$ concentrations of water samples, the concentrations of all samples were then adjusted back to the same reference time when the first water sample was collected. The following formula based on firstorder decay kinetics was used for the adjustment [14]:

$\mathrm{C}=\mathrm{C}_{0} * \operatorname{Exp}\left((\operatorname{Ln}(2) /-3.825) *\left(\mathrm{t}_{1}-\mathrm{t}_{2}\right)\right)$

where:

$\mathrm{C}=$ adjusted ${ }^{222} \mathrm{Rn}$ concentration in groundwater at the time of collection,

$\mathrm{C}_{0}={ }^{222} \mathrm{Rn}$ concentration measured by the LSC,

$t_{1}=$ time at collection of the first groundwater sample

$\mathrm{t}_{2}=$ time at the analysis.

\subsubsection{Rock and Soil Samples}

After classification, $30 \mathrm{~g}$ of rock and soil sample of each type was sent to GeoAnalytical Laboratory of Washington State University to be analyzed by inductively coupled plasma mass spectroscopy (ICP-MS) for uranium content [15].

\subsection{Materials}

Glass water sample bottles for water collections and borosilicate glass scintillation vials for ${ }^{222} \mathrm{Rn}$ analysis were purchased from Fisher Scientific, Inc. (Pittsburgh, PA, USA); scintillator cocktail was purchased from Perkin Elmer (Waltham, MA, USA); all other chemicals were either laboratory or analytical grade; deionized water was used for all dilutions and solution preparations.

\subsection{Geographic Information System Interpolation}

An inverse distance weighted (IDW) module from ArcInfo-ArcMap 9.2 was used to create an interpolation map of ${ }^{222} \mathrm{Rn}$ concentrations at the eight different sampling locations to help visualize possible radon distribution in groundwater of the area. IDW is an interpolation technique that estimates cell values by averaging the sample values in the neighborhood of each processing cell. The closer a point is to the center of the cell being estimated, the more weightage it has in the estimation [16]. For using the IDW module in this study, default parameters were used while creating the IDW interpolation map, the program parameters included exponent of the distance and search radius settings, the exponent of the distance was 2 (second-order function), and search radius was variable since the sampling locations were randomly selected in the study area. No input barrier was selected assuming there were no regions that were obstructing the ${ }^{222} \mathrm{Rn}$ transport in the groundwater.

\subsection{Core Logs of Wells}

The core $\operatorname{logs}$ of wells in the study area were obtained online from IDWR [17].

\section{RESULTS}

Table 1 shows the average count rate (dpm) and converted ${ }^{222} \mathrm{Rn}$ concentrations (activities) measured using the liquid scintillation counter for the 24 water samples. Each sample's activity was measured once per minute for $60 \mathrm{~min}$ utes (60 duplicates), the standard deviation for each sample is given (1-sigma) next to the activity value. The last column on the right in Table $\mathbf{1}$ is the adjusted ${ }^{222} \mathrm{Rn}$ concentration $(\mathrm{C})$ of each sample back-calculated to the time when the first sample was taken and based on first-order decay kinetics (Equation 3), this concentration is the value to be used in all discussions since ${ }^{222} \mathrm{Rn}$ disintegrates continuously with time.

Table 1. Concentrations (Activities) of ${ }^{222} \mathrm{Rn}$ from the Sample Locations of Antelope Creek, Idaho

\begin{tabular}{|c|c|c|c|c|c|c|}
\hline \multirow{2}{*}{\begin{tabular}{|c}
$\begin{array}{c}\text { Sample } \\
\text { Location }\end{array}$ \\
S1A
\end{tabular}} & \multirow{2}{*}{\begin{tabular}{|c|}
$\begin{array}{c}\text { Count Rate } \\
\text { (counts/min) }\end{array}$ \\
86.47 \\
\end{tabular}} & \multirow{2}{*}{\begin{tabular}{|c|}
$\begin{array}{c}\text { Repeated } \\
\text { Counts }\end{array}$ \\
60
\end{tabular}} & \multicolumn{2}{|c|}{$\begin{array}{c}\mathrm{C}_{0}, \\
\text { Activity } \\
(\mathrm{Bq} / \mathrm{L})\end{array}$} & \multicolumn{2}{|c|}{$\begin{array}{c}\mathrm{C}, \\
\text { Adjusted } \\
\text { Activity } \\
(\mathrm{Bq} / \mathrm{L})\end{array}$} \\
\hline & & & 34 & \pm 1 & 46 & \pm 2 \\
\hline S1B & 85.47 & 60 & 33 & \pm 1 & 46 & \pm 1 \\
\hline $\mathrm{S} 1 \mathrm{C}$ & 83.72 & 60 & 32 & \pm 1 & 45 & \pm 1 \\
\hline S2A & 116.35 & 60 & 46 & \pm 1 & 62 & \pm 2 \\
\hline S2B & 117.67 & 60 & 46 & \pm 1 & 63 & \pm 2 \\
\hline $\mathrm{S} 2 \mathrm{C}$ & 113.43 & 60 & 45 & \pm 1 & 61 & \pm 2 \\
\hline $\mathrm{S} 3 \mathrm{~A}$ & 123.47 & 60 & 49 & \pm 2 & 65 & \pm 2 \\
\hline S3B & 117.23 & 60 & 46 & \pm 1 & 62 & \pm 2 \\
\hline $\mathrm{S} 3 \mathrm{C}$ & 117.63 & 60 & 46 & \pm 1 & 62 & \pm 2 \\
\hline S4A & 61.13 & 60 & 23 & \pm 1 & 32 & \pm 1 \\
\hline S4B & 62.33 & 60 & 24 & \pm 1 & 33 & \pm 1 \\
\hline $\mathrm{S} 4 \mathrm{C}$ & 58.98 & 60 & 22 & \pm 1 & 31 & \pm 1 \\
\hline S5A & 108.77 & 60 & 43 & \pm 1 & 60 & \pm 2 \\
\hline S5B & 104.18 & 60 & 41 & \pm 1 & 58 & \pm 2 \\
\hline $\mathrm{S} 5 \mathrm{C}$ & 102.27 & 60 & 40 & \pm 1 & 57 & \pm 2 \\
\hline S6A & 44.38 & 60 & 16 & \pm 1 & 23 & \pm 1 \\
\hline S6B & 45.47 & 60 & 17 & \pm 1 & 24 & \pm 1 \\
\hline S6C & 44.48 & 60 & 16 & \pm 1 & 24 & \pm 1 \\
\hline S7A & 48.62 & 60 & 18 & \pm 1 & 26 & \pm 1 \\
\hline S7B & 49.57 & 60 & 19 & \pm 1 & 27 & \pm 1 \\
\hline S7C & 49.7 & 60 & 19 & \pm 1 & 27 & \pm 1 \\
\hline S8A & 18.28 & 60 & 6 & \pm 0 & 8 & \pm 0 \\
\hline S8B & 17.85 & 60 & 6 & \pm 0 & 8 & \pm 0 \\
\hline $\mathrm{S} 8 \mathrm{C}$ & 17.73 & 60 & 6 & \pm 0 & 8 & \pm 0 \\
\hline
\end{tabular}

Fig. (5) is a bar chart showing the average ${ }^{222} \mathrm{Rn}$ activity with error bar from each sample location and the proposed MCL. It can be seen that except for sampling location S8, all other locations showed ${ }^{222} \mathrm{Rn}$ concentrations in the ground-

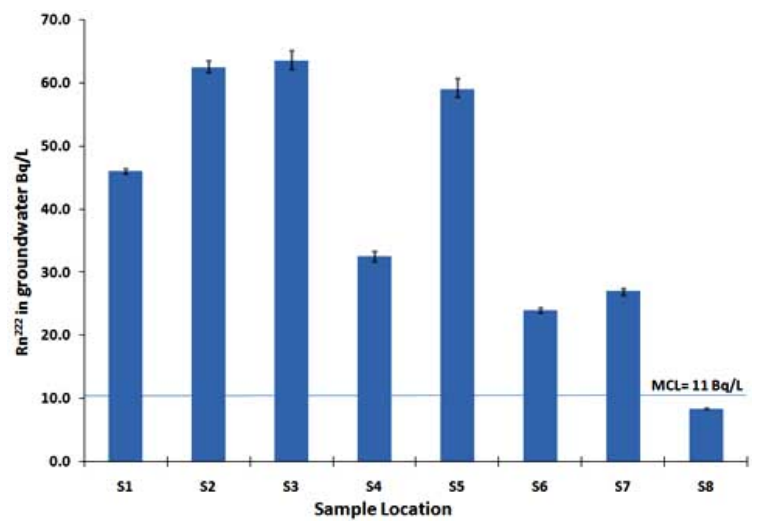

Fig. (5). ${ }^{222} \mathrm{Rn}$ concentrations in water samples. 


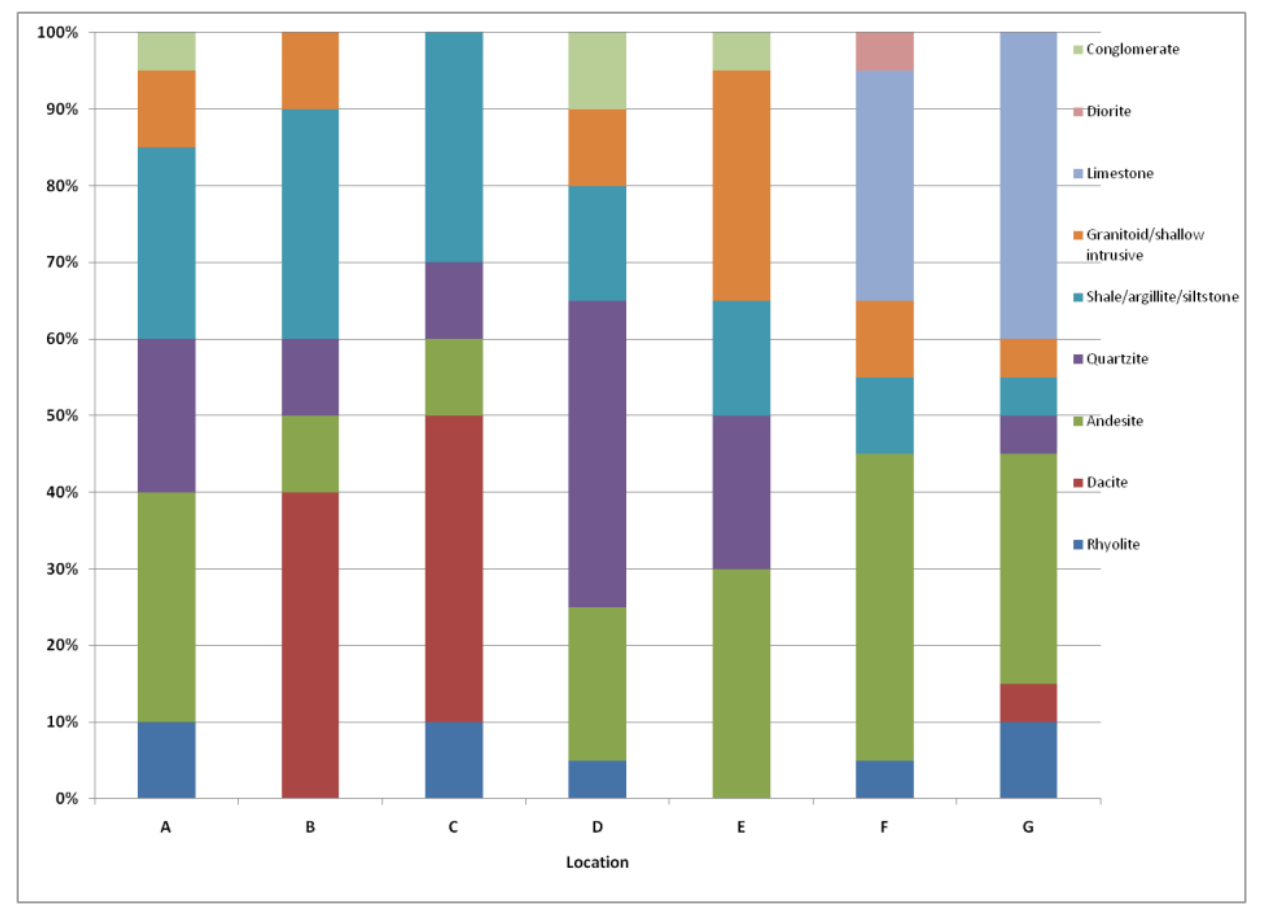

Fig. (6). Composition of rock types of the grid samples in the neighborhood of sample wells.

Table 2. Rock Types from Grid Samples and Their Uranium Contents

\begin{tabular}{|c|c|}
\hline Rock Type & $\begin{array}{c}\text { Uranium Content } \\
\text { (ppm) }\end{array}$ \\
\hline Andesite & \\
\hline 1 & 4.14 \\
\hline 2 & 3.98 \\
\hline 3 & 2.87 \\
\hline Basalt & 2.34 \\
\hline Conglomerate & 1.88 \\
\hline Dacite & \\
\hline 1 & 6.41 \\
\hline 2 & 4.92 \\
\hline 3 & 4.02 \\
\hline Diorite & 5.82 \\
\hline Limestone & 2.18 \\
\hline Quartzite & \\
\hline 1 & 0.56 \\
\hline 2 & 0.82 \\
\hline Rhyolite & \\
\hline 1 & 5.19 \\
\hline 2 & 5.76 \\
\hline 3 & 3.65 \\
\hline Shale /argillite /siltstone & \\
\hline 1 & 4.70 \\
\hline 2 & 2.56 \\
\hline 3 & 4.95 \\
\hline Shallow intrusive / granetoid & \\
\hline 1 & 2.85 \\
\hline 2 & 4.10 \\
\hline 3 & 4.03 \\
\hline
\end{tabular}

water were significantly greater than the proposed MCL (11 $\mathrm{Bq} / \mathrm{L})$. Concentration of ${ }^{222} \mathrm{Rn}$ in groundwater in general decreased from the southwestern to the northeastern corner, thus the groundwater loses ${ }^{222} \mathrm{Rn}$ as it flows through the valley. The reason why the concentration of ${ }^{222} \mathrm{Rn}$ is so high is still unclear, especially in the southwestern corner of the valley.

Figure 6 shows the composition of rock types from the 7 rock/soil grids that were collected along the groundwater flow and near the sampling wells, this information was developed from the rock and soil analyses of the sample grids. Table $\mathbf{2}$ is the contents of uranium from each rock types measured by ICP-MS. The concentrations of uranium in the samples varied from $0.56 \mathrm{ppm}$ in quartzite to $6.41 \mathrm{ppm}$ in Dacite. Similar ${ }^{222} \mathrm{Rn}$ concentrations in groundwater were also observed by Wanty et al. [18] in minerals having U contents that were in the same range. So the high ${ }^{222} \mathrm{Rn}$ contents in the groundwater of the sample wells are anticipated given the rock formations in the area are having relatively high $U$ contents.

While addressing a complex phenomenon such as ${ }^{222} \mathrm{Rn}$ generation and its transport in groundwater, it might be useful to create an interpolation map using available information and correlate them with other information systems. Geographic Information System (GIS) can help creating such a mapping system that incorporates all the available information. Skeppström and Olofsson conducted a similar study in Sweden predicting ${ }^{222} \mathrm{Rn}$ in groundwater using GIS techniques: the authors studied effect of geology, topography and ${ }^{238} \mathrm{U}$ of the bedrock on ${ }^{222} \mathrm{Rn}$ concentrations in the groundwater. A similar effort was conducted in this study [19].

Fig. (7) showed the IDW interpolation using the average ${ }^{222} \mathrm{Rn}$ concentration of the eight sampling wells. The results were plotted on an USGS (U.S. Geological Survey) map by using rock formations of the areal outcrops [20]. (The layer was made with 15 percent transparence so that the underlying rock formations can be seen. There were nine classes (concentrations) participating in the IDW interpolation. These classes are default classes generated by the ArcGIS program [21].) It shows which regions of surface deposits 


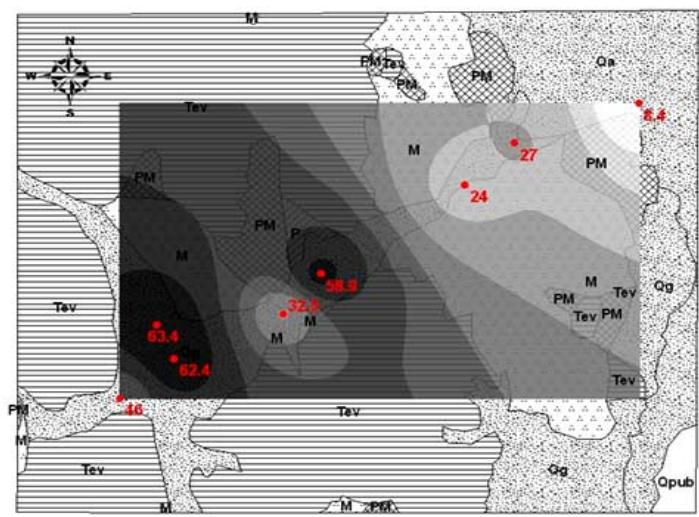

$0 \quad 12$ Kilometers

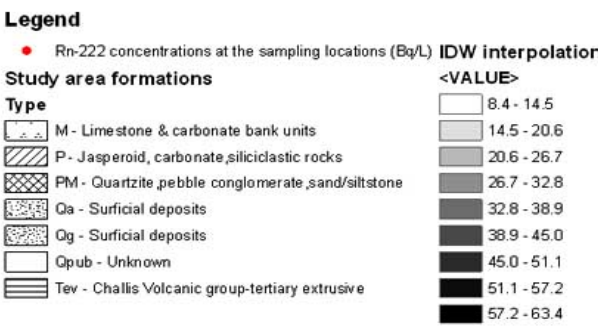

Fig. (7). Rock formation of the study area and average ${ }^{222} \mathrm{Rn}$ concentration at each sampling location with IDW interpolation.

are having higher concentrations of ${ }^{222} \mathrm{Rn}$ in the groundwater. As the contributing units change from Challis volcanic rocks to tertiary rock units (such as jasperoids) and limestone and carbonate bank units, the concentrations of ${ }^{222} \mathrm{Rn}$ tend to decrease accordingly. These results are similar to the findings of Skeppström and Olofsson that there was a correlation between the rock type, thus the uranium contents (Table 1), and ${ }^{222} \mathrm{Rn}$ concentration in groundwater.

A two-dimensional visualization of how ${ }^{222} \mathrm{Rn}$ concentration in the groundwater is distributed over the study area is provided in Fig. (7); however, it is also possible to fathom subsurface factors such as faults, fractures and underlying rocks/sediments to better demonstrate how the local geology may affect ${ }^{222} \mathrm{Rn}$ distribution in the groundwater with similar GIS techniques. Due to the lacking of sufficient geological information in the studies area, available core log information [17] was gathered from some of the wells and a pointwise three-dimensional diagram was created in order to show how the aforementioned factors may be used to illustrate the ${ }^{222} \mathrm{Rn}$ concentration profile.

Fig. (8a and $\mathbf{8 b}$ ) depict a three-dimensional visualization of the area using three available core logs obtained from IDWR. The log information indicated that water level in the area varied from $1.8 \mathrm{~m}$ to $17.6 \mathrm{~m}$ at the three locations. The core $\log$ s were mainly consisted of shales, gravel and large rocks and clay. It is understood that the mineral information of the core logs may not be accurately described the rock formation, but the groundwater levels of the logs should be relatively reliable. Thus, the groundwater levels of the area can fluctuate irregularly as it is demonstrated by the core

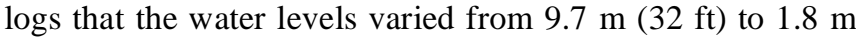
$(6 \mathrm{ft})$ to $17.6 \mathrm{~m}(56 \mathrm{ft})$ at Core 1,2 , and 3 , respectively.

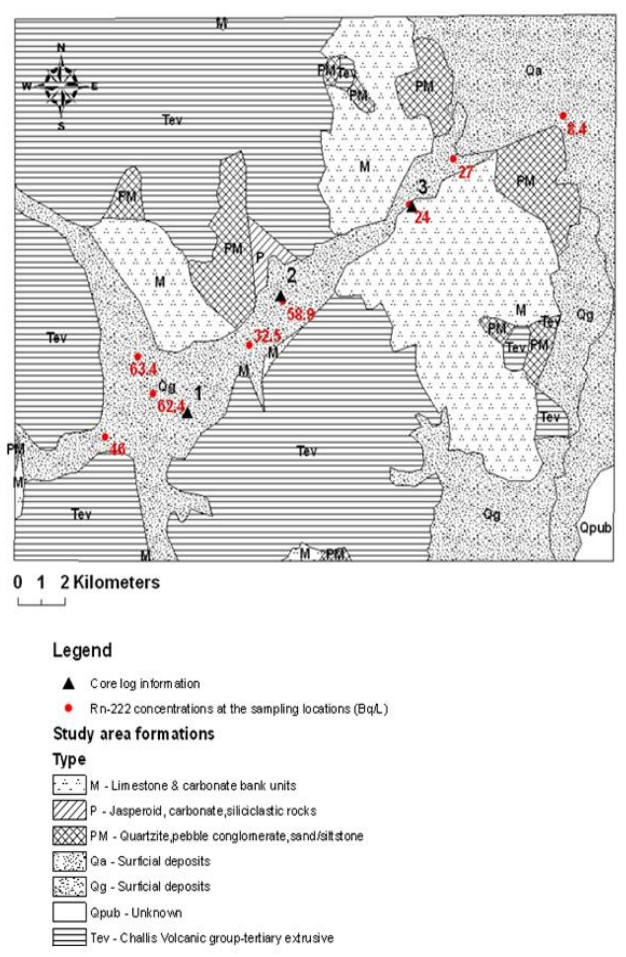

a.

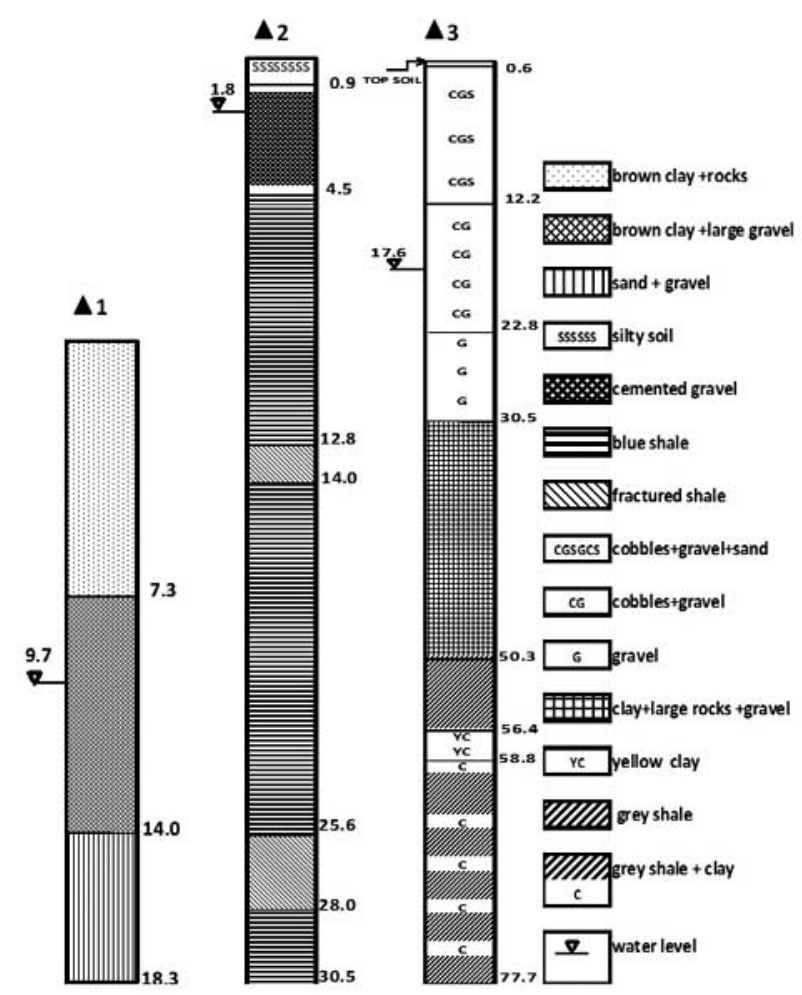

b.

Fig. (8). a. Locations in the study area from which core log information was available. b. Core log information for the three locations in the study area (depths are in $\mathrm{m}$ ). 


\section{DISCUSSIONS AND CONCLUSIONS}

There were seven out of eight sampling wells possessed measured ${ }^{222} \mathrm{Rn}$ concentrations greater than the EPA proposed MCL, in general, ${ }^{222} \mathrm{Rn}$ concentrations decreased from the southwestern corner to the northeastern corner of the Antelope Creek valley. Rocks and soils collected from seven sample grids along the sample wells revealed U concentrations varied from 0.56 to $6.41 \mathrm{ppm}$, this is a good indication of why the groundwater samples were having ${ }^{222} \mathrm{Rn}$ concentrations much higher than the proposed MCL and the results were consistent with measurements reported from other regions that have similar $\mathrm{U}$ contents in the minerals [18].

A GIS technique using basic interpolation method was applied in this study to visualize the distribution of ${ }^{222} \mathrm{Rn}$ in the groundwater, although more advanced method such as Kriging [22] may be applied if more sample information was known. The interpolation might not reflect the actual concentrations of the ${ }^{222} \mathrm{Rn}$ in the area but it can portray the likely distributions of ${ }^{222} \mathrm{Rn}$ with the model assumptions and available information. The interpolation models can be used to gain an overall perspective of ${ }^{222} \mathrm{Rn}$ concentrations for a study area, as well as to project potential health risk.

The half life of ${ }^{222} \mathrm{Rn}$ is 3.8 days, it thus cannot travel a long distance before total disintegration and transforming into other elements. For example, with a fast groundwater velocity assumption of $3 \mathrm{~m} /$ day, concentration of ${ }^{222} \mathrm{Rn}$ in groundwater at S1 well would have decayed to $5.8 \mathrm{~Bq} / \mathrm{L}$ (about half of proposed MCL) in less than 12 days, whereas the groundwater would only travel $36 \mathrm{~m}$. Considering the diagonal length of the area is nearly $1000 \mathrm{~km}$, the assumed distance of the groundwater traveled is negligible. Therefore, it is reasonable to assume that the groundwater ${ }^{222} \mathrm{Rn}$ concentrations at the wells we conducted the measurements are in a steady-state, and there are constant infusions of ${ }^{222} \mathrm{Rn}$ discharged into the aquifer to make up the disappearing of decaying ${ }^{222} \mathrm{Rn}$.

The aquifer is not entirely contained by any particular rock type but there is a great variability in the composition of the aquifer material. The rocks/sediments in the Antelope Creek valley are directly derived from the surrounding rock units. These units may contain considerable amounts of ${ }^{238} \mathrm{U}$ and ${ }^{226} \mathrm{Ra}$ [1]. The highest concentrations of ${ }^{222} \mathrm{Rn}$ are observed near tertiary extrusive rocks and jasperoid units. These rocks are also known to possess high concentrations of ${ }^{238} \mathrm{U}$ which eventually generate ${ }^{222} \mathrm{Rn}$ [23]. Results from rock and soil samples and IWD interpretations indicated that there was a good correspondence between rock types and ${ }^{222} \mathrm{Rn}$ concentrations in the groundwater.

Many factors may affect concentration of ${ }^{222} \mathrm{Rn}$ in groundwater: such as ${ }^{238} \mathrm{U}$ and ${ }^{226} \mathrm{Ra}$ that are the parent radionuclides of ${ }^{222} \mathrm{Rn}$, porosity of the parent radionuclides bearing materials and the surrounding rocks and sediment, rock sizes, complexation of the parent radionuclides, and sorption capacity of the surrounding materials $[24,25]$. The area is also known to possess uranium $\left(\mathrm{U}_{3} \mathrm{O}_{8}\right)$ ore [26] which can be a contributing factor to the ${ }^{222} \mathrm{Rn}$ concentration in groundwater. The influence of these factors to ${ }^{222} \mathrm{Rn}$ in groundwater and information of their effects are only discretely available in the public domain. Incidentally, all the sampling sites are bordered between Custer and Butte County. Within Butte County, the bladder, liver, and kidney cancer rate are two standard deviations above the national average, which is clinically significant [27]. Nevertheless, the high concentration of ${ }^{222} \mathrm{Rn}$ in groundwater may post a potential health risk to the local residents [4]. Are the high incidents of certain cancer rates tied with the high concentration of ${ }^{222} \mathrm{Rn}$ in groundwater? Or these two issues are mutually exclusive remain to be topics of investigations. Further research on the rocks' formation and sediments, the local hydrology, and how other physical factors mentioned above may affect the production and transport of ${ }^{222} \mathrm{Rn}$ would provide better insight to these issues. Lastly, it should be noted that a common reference point should be used while reporting ${ }^{222} \mathrm{Rn}$ concentration due to its rapid natural decay to avoid underreporting of measurements.

\section{ACKNOWLEDGEMENTS}

The authors would like to thank Dr. James Mahar, Dr. Richard Brey, and Mr. Kevin Claver of ISU for supporting the project. We would also like to recognize Inland Northwest Research Alliance (INRA) for partially funding the project.

\section{REFERENCES}

[1] Gundersen LCS, Schumann RR, Otton JK, Dubiel RF, Owen DE, Dickinson KA. Geology of radon in the United States. In: Gates AE, Gundersen LCS, Eds. Geologic Controls on Radon Special Paper 271. Geological Society of America, Boulder, Colorado 1992; pp. 1-16.

[2] National Cancer Institute FactSheet. Radon and Cancer: Questions and Answers. http://www.cancer.gov/cancerTopics/factsheet/Risk/ radon, [accessed July 31. 2009].

[3] Paulus LR. An evaluation of radon concentrations in ground water from wells and springs in the State of Idaho. M.S. Thesis, Idaho State University, Pocatello, Idaho 1995.

[4] U. S. Environmental Protection Agency (USEPA). Radon. http://www.epa.gov/radon/, accessed January 31. 2008.

[5] U. S. Environmental Protection Agency (USEPA). National Primary Drinking Water Regulations, Radon-222. Federal Register: November 2, 1999; 64 (211), pp. 59245-94.

[6] Idaho Administrative Code (IAC). IDAPA 58.01.11 Department of Environmental Quality Ground Water Quality Rule. http://adm.idaho.gov/adminrules/rules/idapa58/0111.pdf, [accessed January 31. 2008].

[7] Fitzgerald B, Hopke PK, Datye V, Raunemaa T, Kuuspalo K. Experimental Assessment of the Short- and Long-Term Effects of ${ }^{222} \mathrm{Rn}$ from Domestic Shower Water on the Dose Burden Incurred in Normally Occupied Homes. Environ Sci Technol 1997; 31: 1822-9.

[8] Hopke PK, Borak TB, Doull J, et al. Health risks due to radon in drinking water. Environ Sci Technol 2000; 34: 921 -6.

[9] Idaho Department of Water Resources (IDWR) Internet Map Server. http://mapall.idwr.state.id.us, accessed December 10. 2005.

[10] U. S. Environmental Protection Agency (USEPA). National Primary Drinking Water Regulations, Radon-222. Federal Register: November 2, 1999, 64 (211), pp. 59295-344.

[11] Xinwei L. Analysis of radon concentration in drinking water in Baoji (China) and the associated health effects. Radiat Prot Dosim 2006; 121: 452-5.

[12] Eappen KP, Nair RN, Mayyaa YS. Simultaneous measurement of radon and thoron using Lucas scintillation cell. Radiat Meas 2008; 43: 91-7.

[13] Prichard HM, Gessel TF. Rapid determination of radon-222 concentrations in water with a commercial liquid scintillation counter. Health Phys 1977; 33: 577-81.

[14] Metcalf \& Eddy, Water Engineering Treatment and Reuse, Boston, MA McGraw Hill Co., 2003; pp. 206-63. 
[15] Trace Element Analyses of Rocks and Minerals by ICP-MS. GeoAnalytical Lab Technical Notes. http://www.sees.wsu.edu/ Geolab/note/icpms.html, [accessed August 1. 2009].

[16] Demsar U, Skeppström K. ScanGIS'2005 - The 10th Scandinavian Research Conference on Geographical Information Science, Stockholm, Sweden 2005.

[17] IDWR. http://www.idwr.idaho.gov/apps/appswell/searchWC.asp, [accessed August 1, 2009].

[18] Wanty RB, Lawrence EP, Gundersen LCS. A theoretical model for the flux of radon from rock to ground water In: Gates AE, Gundersen LCS, Eds. Geologic Controls on Radon Special Paper 271. Geological Society of America, Boulder, Colorado 1992; pp. 73-8.

[19] Skeppström K, Olofsson B. A prediction method for radon in groundwater using GIS and multivariate statistics. Sci Total Environ 2006; 367: 666-80.

[20] Wilson AB, Skipp B. Geologic Map of the Eastern Part of the Challis National Forest and Vicinity, Idaho, Map I--2395, Miscellaneous Investigations Series, US Geological Survey 1994.
[21] ArcGIS Desktop Help 9.2. http://webhelp.esri.com/arcgisdesktop/ 9.2/index.cfm?TopicName=Implementing_Inverse_Distance_Weighted_(IDW), [accessed June 1.2009].

[22] Salih I, Pettersson HBL, Sivertun A, Lund E. Spatial correlation between radon $\left({ }^{222} \mathrm{Rn}\right)$ in groundwater and bedrock uranium $\left({ }^{238} \mathrm{U}\right)$ : GIS and geostatistical analyses. J Spatial Hydrol 2002; 2: 1-10.

[23] Keller EA. Environmental Geology, New Jersey, Prentice-Hall Inc., Upper Saddle River, 2000; pp. 342-71.

[24] Porcelli D, Swarzenski PW. The behavior of U- and Th-series nuclides in groundwater. Reviews in Mineralogy and Geochemistry. Geochemical Society, Mineralogical Society of America 2003; vol. 52: pp. 317-56.

[25] Wong CS, Chin Y, Gschwend PM. Sorption of radon-222 to natural sediments. Geochim Cosmochim Acta 1992; 56: 3923-32.

[26] Farahmand SH. Uranium potential in the Spar Canyon and Road Creek areas, Custer County, Idaho. M.S. Thesis, Idaho State University, Pocatello, Idaho 1980

[27] Cancer Facts and Figures. http://www.cancer.org/docroot/home/ index. asp., [accessed August. 1. 2007].

(C) Gokhale and Leung; Licensee Bentham Open.

This is an open access article licensed under the terms of the Creative Commons Attribution Non-Commercial License (http://creativecommons.org/licenses/_by-nc/3.0/) which permits unrestricted, non-commercial use, distribution and reproduction in any medium, provided the work is properly cited. 